\title{
Sousa, D. A. (Ed.). (2014). Neurociencia educativa: Mente, cerebro y educación (Vol. 131). Madrid, España: Narcea Ediciones. ISBN: 978-84-277-2036-7
}

David A. Sousa, un prestigiós assessor internacional en neurociència aplicada a l'educació, ens ofereix, a través d'un llenguatge pla i un format i estil senzill, una obra que actua com a pont d'unió entre la neurociència i l'educació per tal de que tant docents com el públic en general interessat en l'àmbit educatiu pugui seguir innovant pedagògicament.

Lluny de ser un manual destinat a experts de les reaccions nervioses, es tracta d'una aproximació al funcionament i comportament del cervell per tal de que el lector pugui entendre aspectes com, per exemple, la rellevància que tenen la curiositat, la interacció activa i dinàmica o l'emoció en l'adquisició de nous coneixements i, en definitiva, en l'aprenentatge. Per aconseguir-ho, el llibre proporciona al lector una àmplia panoràmica de les possibles aplicacions de la neurociència en l'educació a través d'una combinació binària de teoria i d'estratègies didàctiques diverses.

Com bé argumenta Sousa, així com els set autors que participen en l'elaboració del llibre, per tal de millorar els procediments didàctics i d'aprenentatge, els agents educatius requereixen, almenys, un coneixement bàsic sobre com aprèn el cervell, com processa la informació, com controla els estats conductuals i les emocions o com de fràgil pot arribar a ser quan rep certs estímuls tals com l'estrès.

Sens dubte, els centres educatius i les metodologies didàctiques es troben en un canvi continu. No obstant, aquest canvi no s'està produint a una velocitat suficient. Es requereixen innovacions pedagògiques inspirades en teories neurocientífiques avalades per tal de que les necessitats de l'alumnat i el que actualment ofereix el sistema educatiu es trobi en equilibri. Un clar exemple d'aquesta manca de sintonia es troba en l'actitud d'un important número de discents, els quals consideren que l'escola es un espai avorrit i, fins i tot, frustrant. Davant d'aquesta situació d'alarma, resulta necessària la transformació dels sistemes educatius a través dels coneixements que ens ofereix la neurociència per a que aquests siguin, realment, espais on l'alumnat no només hi estigui físicament sinó que es senti a gust, estimulat, motivat i valorat.

En quant a l'estructura de l'obra, aquesta es troba dividida en tres grans blocs que, tot i estar escindits, segueixen un fil conductor coherent i fàcil de seguir. Pel que fa a la primera part, formada per tres capítols, aquesta es centra en el cervell, la seva fisiologia i el desenvolupament que realitza. És també en aquesta part on s'estudien les implicacions pedagògiques de la neurogènesi, així com les fases crítiques, les sinapsis neuronals o el desenvolupament de les àrees terciàries o d'associació del cervell durant l'adolescència.

A continuació, la segona part es centra en el cervell a l'escola. És a dir, aborda temes com l'aprenentatge que es duu a terme en el cervell durant l'aprenentatge de la lectoescriptura o el càlcul, en les possibles diferències que es troben en el cervell i el seu funcionament en funció del sexe de l'individu o en les 
necessitats socials i acadèmiques d'alumnes amb dificultats d'aprenentatge tals com l'autisme, la dislèxia o la discalcúlia.

Finalment, en la tercera part, es mostren algunes de les estratègies didàctiques, així com capítols sobre com reduir l'estrès a l'aula i afavorir la implicació, la concentració i l'estímul de l'alumne a nivell cerebral. Sens dubte, el cervell humà resulta ser un element imprescindible en el procés d'ensenyament $\mathrm{i}$ aprenentatge. A la vegada, encara avui és un gran desconegut, doncs moltes són les incògnites que ens queden per resoldre. Per tant, sembla ser del tot lògic que si el que volem es optimitzar en termes d'eficàcia $i$ eficiència aquest procés d'ensenyament $i$ d'aprenentatge, hem d'apostar per una neurociència de qualitat així com en la seva aplicació pedagògica.

Mireia Vendrell Morancho Universidad Complutense de Madrid 